\title{
Buprenorphine Prescribing Practices and Exposures Reported to a Poison Center — Utah, 2002-2011
}

Buprenorphine is an effective medication for the treatment of opioid dependence. Its use has increased in the United States as a result of the Drug Addiction Treatment Act of 2000, which allowed physicians to prescribe certain medications as part of office-based treatment for opioid addiction. In France, widespread use of medication-assisted therapy, primarily buprenorphine treatment, was associated with an $80 \%$ decrease in overdose deaths from heroin or cocaine from 465 in 1996 to 89 in 2003 (1). With the expanded use of buprenorphine, an increase in exposures among children and adults has been reported in the United States. These exposures (including unintentional and intentional, therapeutic and nontherapeutic) have resulted in adverse effects and, in a small number of cases, death. To assess statewide increases in buprenorphine use and the number of reported exposures, the Utah Department of Health analyzed data from the Utah Controlled Substance Database (CSD) and the Utah Poison Control Center (PCC). The results of that analysis indicated a statewide increase in the annual number of patients prescribed buprenorphine from 22 in 2002 to 9,793 in 2011, and a concurrent increase in the annual number of prescribers writing buprenorphine prescriptions from 16 to 1,088 . Over the same period, the number of exposures to buprenorphine reported annually to the PCC increased from six to 81 . However, comparison of the ratios of buprenorphine exposures to patients and prescribers in 2002 with data for 2011 indicated substantial decreases from 6/22 for patients and 6/16 for prescribers in 2002 to $81 / 9,793$ for patients and $81 / 1,088$ for prescribers in 2011. Three of the total 462 buprenorphine exposures reported during 20022011 in Utah, in a teen and two adults, were associated with fatal outcomes. Increased buprenorphine prescribing in Utah during 2002-2011 likely represents expanded access to critically needed opioid addiction treatment; however, safeguards should be in place to prevent adverse effects. Prescribers and pharmacists are encouraged to counsel patients carefully regarding the safe use, storage, and disposal of buprenorphine.
The epidemic of opioid addiction and related overdose deaths is a well-described and growing public health problem in the United States (2). Numerous barriers to accessing opioid addiction treatment have been identified.* Buprenorphine was approved by the Food and Drug Administration in 2002 for the treatment (alone or in combination with naloxone) of opioid dependence $(3,4)$. The efficacy of buprenorphine in the treatment of opioid dependence has consistently been demonstrated (5), and its use has been associated with new types of patients receiving addiction treatment. Similar to other opioids, buprenorphine produces euphoria and respiratory depression in a dose-dependent manner. However, unique to buprenorphine, these effects increase until, at moderate doses, the effects reach a plateau and no longer continue to increase, making respiratory depression less likely in a habituated opioid user $(4,6)$. This "ceiling effect" has raised concern that some prescribers and patients might think buprenorphine unlikely to cause any adverse effects ( 6 ). Studies have indicated that, in an opioid naïve patient, respiratory depression might occur before reaching this ceiling, especially in young children $(\sigma)$.

*Additional information available at http://www.ncbi.nlm.nih.gov/books/ nbk14677.

\section{INSIDE}

1002 Early Warning Disease Surveillance After a Flood Emergency - Pakistan, 2010

1008 Expanding Poliomyelitis and Measles Surveillance Networks to Establish Surveillance for Acute Meningitis and Encephalitis Syndromes Bangladesh, China, and India, 2006-2008

1013 QuickStats

Continuing Education examination available at http://www.cdc.gov/mmwr/cme/conted_info.html\#weekly.

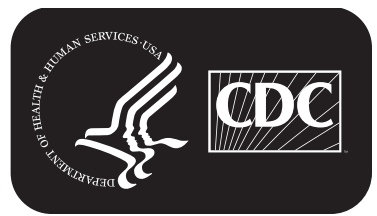

U.S. Department of Health and Human Services Centers for Disease Control and Prevention 
What is already known on this topic?

Opioid addiction is a well-described and growing public health problem in the United States. In 2002, buprenorphine was approved by the Food and Drug Administration for the treatment (alone or in combination with naloxone) of opioid dependence.

What is added by this report?

In Utah, the annual number of prescribers writing prescriptions for buprenorphine increased 67-fold, from 16 in 2002 to 1,088 in 2011 , and the annual number of patients filling buprenorphine prescriptions increased 444-fold, from 22 to 9,793. During the same period, as the number of prescriptions increased, the annual number of buprenorphine exposures increased 13-fold, from six to 81, with exposures primarily among adults aged $\geq 20$ years and children aged $\leq 5$ years. Of 462 exposures, three $(<1 \%)$ were fatal.

What are the implications for public health practice?

Despite buprenorphine's effectiveness in the treatment of opioid dependence, nontherapeutic use, both misuse and unintentional exposure, can have adverse outcomes. Expanded use of buprenorphine for the treatment of opioid dependence is important to improve public health. Through education and counseling of prescribers, pharmacists, and patients regarding the safe use, storage, and disposal of this drug, adverse effects likely can be reduced.

For this report, data for 2002-2011 were analyzed from the state's CSD and PCC. The CSD tracks all outpatient (but not inpatient) prescriptions for Schedule II-V drugs dispensed in
Utah. CSD is maintained by the Division of Occupational and Professional Licensing within the Utah Department of Commerce. The PCC maintains data on reported human exposures to buprenorphine and other drugs (including intentional and unintentional, therapeutic and nontherapeutic exposures). Standardized information collected for each exposure includes age, sex, substance, route of exposure, reason for exposure, location of exposure, location of caller, therapy provided, clinical effects, management location, and medical outcome.

\section{CSD Findings}

During 2002-2011, the number of prescribers writing prescriptions for buprenorphine increased 67-fold, from 16 in 2002 to 1,088 in 2011, and the number of patients filling buprenorphine prescriptions increased 444-fold, from 22 in 2002 to 9,793 in 2011. In 2011, the 106,415 buprenorphine prescriptions recorded in the CSD amounted to $2 \%$ of the total 5,291,530 controlled substance prescriptions.

The patients whose prescriptions for buprenorphine were recorded in the CSD during 2002-2011 were predominantly (59.7\%) men. The mean age of the persons for whom exposures were reported was 34.7 years (standard deviation: 12.6 years), and the median age was 31 years (range: $<1$ to 109 years).

\section{PCC Findings}

From 2002 to 2011, the number of exposures to buprenorphine reported annually to the PCC increased approximately

The MMWR series of publications is published by the Office of Surveillance, Epidemiology, and Laboratory Services, Centers for Disease Control and Prevention (CDC), U.S. Department of Health and Human Services, Atlanta, GA 30333.

Suggested citation: Centers for Disease Control and Prevention. [Article title]. MMWR 2012;61:[inclusive page numbers].

\section{Centers for Disease Control and Prevention}

Thomas R. Frieden, MD, MPH, Director

Harold W. Jaffe, MD, MA, Associate Director for Science

James W. Stephens, PhD, Director, Office of Science Quality

Stephen B. Thacker, MD, MSc, Deputy Director for Surveillance, Epidemiology, and Laboratory Services

Stephanie Zaza, MD, MPH, Director, Epidemiology and Analysis Program Office

MMWR Editorial and Production Staff

Ronald L. Moolenaar, MD, MPH, Editor, MMWR Series

John S. Moran, MD, MPH, Deputy Editor, MMWR Series

Teresa F. Rutledge, Managing Editor, MMWR Series

Douglas W. Weatherwax, Lead Technical Writer-Editor

Donald G. Meadows, MA, Jude C. Rutledge, Writer-Editors

Martha F. Boyd, Lead Visual Information Specialist

MMWR Editorial Board

William L. Roper, MD, MPH, Chapel Hill, NC, Chairman

Matthew L. Boulton, MD, MPH, Ann Arbor, MI

Virginia A. Caine, MD, Indianapolis, IN

Jonathan E. Fielding, MD, MPH, MBA, Los Angeles, CA David W. Fleming, MD, Seattle, WA

William E. Halperin, MD, DrPH, MPH, Newark, NJ

King K. Holmes, MD, PhD, Seattle, WA

Deborah Holtzman, PhD, Atlanta, GA

Timothy F. Jones, MD, Nashville, TN
Maureen A. Leahy, Julia C. Martinroe,

Stephen R. Spriggs, Terraye M. Starr Visual Information Specialists

Quang M. Doan, MBA, Phyllis H. King Information Technology Specialists

\author{
Dennis G. Maki, MD, Madison, WI \\ Patricia Quinlisk, MD, MPH, Des Moines, IA \\ Patrick L. Remington, MD, MPH, Madison, WI \\ John V. Rullan, MD, MPH, San Juan, PR \\ William Schaffner, MD, Nashville, TN \\ Dixie E. Snider, MD, MPH, Atlanta, GA \\ John W. Ward, MD, Atlanta, GA
}


13-fold, from six to 81 . The number of exposures to buprenorphine began to rise significantly in 2004 overall, whereas a similar rise among children aged $\leq 5$ years did not begin until 2006 (Figure). However, comparison of the ratios of buprenorphine exposures to patients and prescribers in 2002 with data for 2011 indicated substantial decreases from $6 / 22$ for patients and 6/16 for prescribers in 2002 to $81 / 9,793$ for patients and 81/1,088 for prescribers in 2011. Of the 462 exposures recorded in the PCC database during 2002-2011, $250(54.1 \%)$ were among adults aged $\geq 20$ years, $179(38.7 \%)$ were among children aged $\leq 5$ years, and $33(7.1 \%)$ were among persons aged 6-19 years (Figure). Nearly all (94\%) of the exposures among children aged $\leq 5$ years were to sublingual tablets rather than to the buprenorphine film product, which was not approved until 2010.

The most common clinical effects reported in children aged $\leq 5$ years were drowsiness in $105(58.6 \%)$, vomiting in $47(26.2 \%)$, respiratory depression in $34(19.0 \%)$, miosis in $27(15.1 \%)$, agitation in $18(10.1 \%)$, and tachycardia in $15(8.4 \%)$. Respiratory arrest was reported in three (1.7\%) children. In adults, the most common clinical effects included drowsiness in $72(28.8 \%)$, vomiting in $53(21.2 \%)$, agitation in $52(20.8 \%)$, nausea in $49(19.6 \%)$, confusion in $28(11.2 \%)$, dizziness in $28(11.2 \%)$, diaphoresis in $21(8.4 \%)$, tachycardia in $17(6.8 \%)$, respiratory depression in $14(5.6 \%)$, ataxia in $13(5.2 \%)$, and diarrhea in 13 (5.2\%). Respiratory arrest was noted in two $(0.8 \%)$ adults.

Among adults, 33 exposures (13.2\%) were unintentional, and $126(50.4 \%)$ were intentional (suicidal intent or intentional misuse or abuse of the medication). Of the 250 adult exposures, $22(8.8 \%)$ were related to withdrawal and 57 $(22.8 \%)$ to adverse reaction to the medication. A known outcome was documented in $164(91.6 \%)$ children aged $\leq 5$ years, and $42(25.6 \%)$ of those outcomes had a moderate or major effect. In adults, a known outcome was documented in 220 $(88.0 \%)$ exposures, and $47(21.4 \%)$ of those outcomes had a moderate, major, or fatal effect. Three fatal outcomes were reported, including two in adults and one in a teen.

The majority of the 462 persons with exposures were treated in a health-care facility $(247 ; 53.5 \%)$. Of the 247 , a total of

FIGURE. Reported buprenorphine exposures $(\mathrm{N}=462)$, by age group — Utah Poison Control Center, 2002-2011

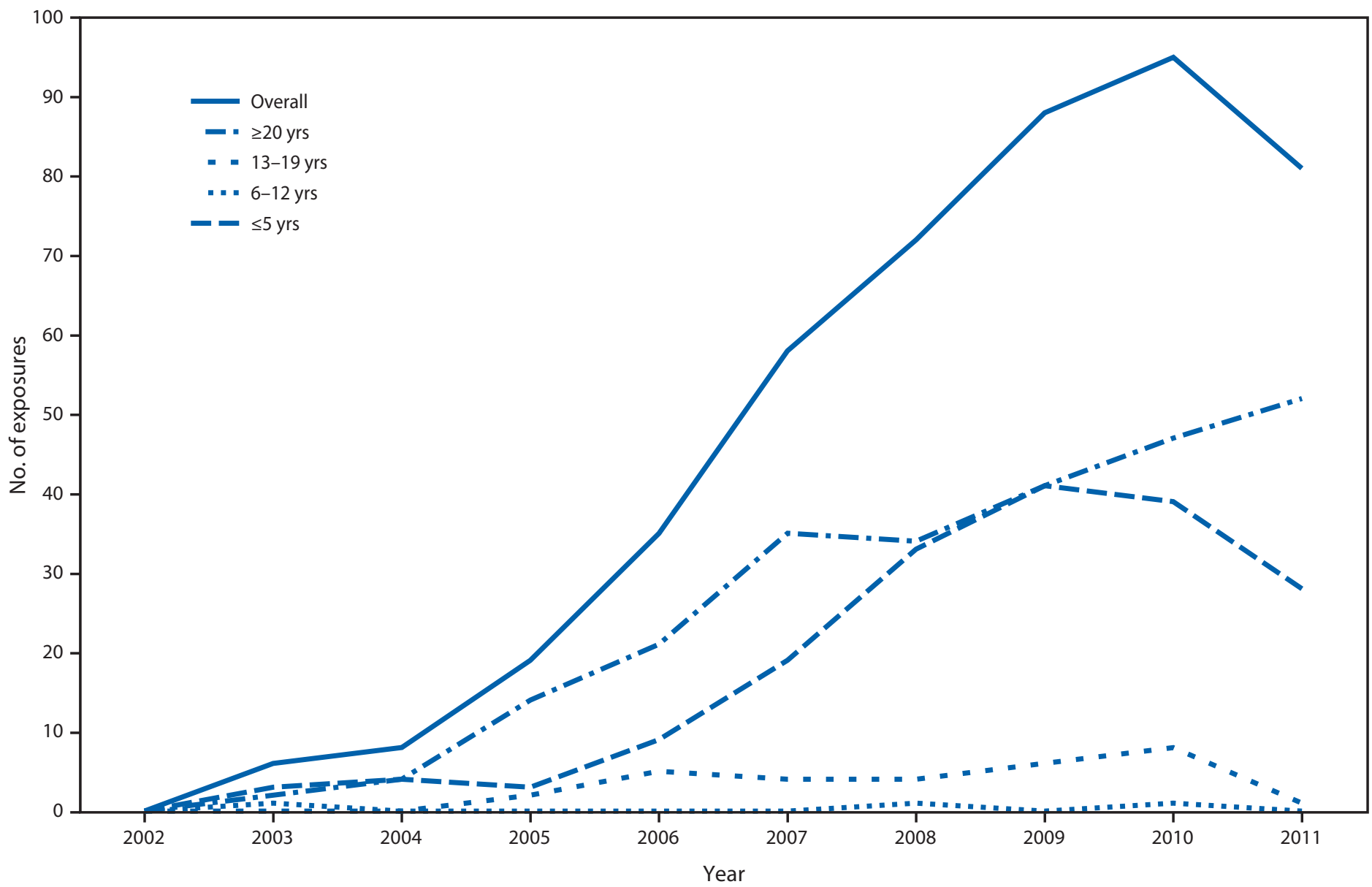


$127(51.4 \%)$ were treated and released from an emergency department, and the remainder were admitted for medical care. A higher proportion of children aged $\leq 5$ years (137; $76.5 \%)$ were treated in a health-care facility, compared with adults $(103 ; 41.2 \%)$.

\section{Reported by}

Karen C. Thomas, PhD, Marty Malheiro, MS, Barbara I. Crouch, PharmD, Utah Poison Control Center; Christina A. Porucznik, PhD, Dept of Family and Preventive Medicine, University of Utah. Corresponding contributor: Christina A. Porucznik, christy.porucznik@utah.edu, 801-581-4330.

\section{Editorial Note}

As use of buprenorphine increased rapidly since 2002, poison control centers throughout the United States observed increases in the number of buprenorphine exposures (7). Increased therapeutic use of buprenorphine likely will help reduce prescription opioid abuse and misuse; however, nontherapeutic or inappropriate use of buprenorphine can cause serious and potentially life-threatening effects among children and adults. Young children exploring their environments might lick or ingest this medication, resulting in vomiting, respiratory depression, coma, or death ( 6 ). Results of a study in an Appalachian community suggest that improved access to buprenorphine treatment might help reduce sharing of the medication among adults and teens or diversion for nontherapeutic use that could cause adverse effects (8).

The increase in buprenorphine use has expanded access to opioid addiction treatment in the office-based setting. This presents new opportunities for health-care providers to reduce morbidity and mortality related to opioid addiction and to mitigate risks associated with nontherapeutic use of this drug. Prescriber and pharmacist counseling of patients regarding the safe use, storage, and disposal of this medication can help prevent adverse consequences from unintentional exposure among children or diversion and experimentation among teens and adults who are opioid naïve. In certain cases, health-care provider counseling might prevent a fatality. In several cases, investigators found that help was not sought immediately after exposure, likely because a child was not observed to have swallowed a tablet or placed packaging in its mouth, only to be found later with respiratory effects. Counseling by health-care providers about the potential dangers to children from licking a buprenorphine film package or holding a sublingual tablet in the mouth, even briefly, might help caregivers learn the importance of early intervention in any buprenorphine exposure.
The findings in this report are subject to at least two limitations. The CSD limits identifiers and does not include information on diagnosis; therefore, it is not possible to determine the reason for prescribing buprenorphine or to evaluate the appropriateness of the prescription. The PCC did not add a code for the buprenorphine film product until October 2010; therefore, some exposures to the film product might have been attributed to the sublingual tablet.

The expanded use of buprenorphine as part of office-based treatment is an important tool to reduce morbidity and mortality associated with opioid addiction (9). Education on how to safely use, store, and dispose of buprenorphine is needed to help prevent unintentional exposures. Health-care professionals and members of the public can contact their local poison control center at 800-222-1222 for guidance regarding the adverse consequences of any exposure and the safe use, storage, and disposal of medications such as buprenorphine (Box). Patients and caregivers are encouraged to seek assistance from their pharmacists, prescribers, local poison control centers, and other members of the health-care community for information regarding the safe use of their medications.

BOX. Recommendations to prevent harmful exposures to buprenorphine

Buprenorphine-containing products can be harmful to children not only when a whole tablet or film is swallowed, but also when they are licked or placed in the mouth.

- Keep medication out of sight and out of reach of children.

- Use a locked box, bag, or cabinet for safe storage of medication.

- Always keep medication in its original, labeled prescription container, with child-resistant closure when appropriate.

- Do not place tablets or films on counters, sinks, dressers, or nightstands for later use.

- Discard used buprenorphine film wrapping immediately by folding the package together, placing it in the trash, and securing the trash. Buprenorphine bottles and film wrapping can contain enough leftover medicine to cause problems for young children.

- Do not store medication in your pocket, bag, purse, backpack, or other carrying case.

- Avoid leaving medication in the bathroom, car, or any publicly accessible space. 


\section{Acknowledgments}

Jacob Crook, Anna Fondario, MPH, Utah Dept of Health.

\section{References}

1. Emmanuelli J, Desenclos JC. Harm reduction interventions, behaviours and associated health outcomes in France, 1996-2003. Addiction 2005; 100:1690-1700.

2. CDC. CDC grand rounds: prescription drug overdoses - a U.S. epidemic. MMWR 2012;61:10-3.

3. Gowing L, Ali R, White JM. Buprenorphine for the management of opioid withdrawal. Cochrane Database Syst Rev 2009;3:CD002025.

4. Sporer KA. Buprenorphine: a primer for emergency physicians. Ann Emerg Med 2004;43:580-4.
5. Mendelson J, Flower K, Pletcher MJ, Galloway GP. Addiction to prescription opioids: characteristics of the emerging epidemic and treatment with buprenorphine. Exp Clin Psychopharmacol 2008;16:435-41.

6. Pedapati EV, Bateman ST. Toddlers requiring pediatric intensive care unit admission following at-home exposure to buprenorphine/naloxone. Pediatr Crit Care Med 2011;12:e102-7.

7. Durback-Morris LF, Scharman EJ. Are children the unintended victims of changes in buprenorphine prescribing practices [Abstract]? Clin Toxicol 2010;48:616.

8. Lofwall MR, Havens JR. Inability to access buprenorphine treatment as a risk factor for using diverted buprenorphine. Drug Alcohol Depend 2012;126:379-83.

9. Kresina TF, Lubran R. Improving public health through access to and utilization of medication assisted treatment. Int J Environ Res Public Health 2011;8:4102-17. 


\section{Early Warning Disease Surveillance After a Flood Emergency — Pakistan, 2010}

During July-August 2010, Pakistan experienced extreme flooding that affected approximately 18 million persons. In response to the emergency, Pakistan's Ministry of Health and the World Health Organization (WHO) enhanced an existing disease early warning system (DEWS) for outbreak detection and response. This report summarizes surveillance results early after implementation, describes system usefulness, and identifies areas for strengthening. Daily disease counts were reported from health facilities in four provinces containing $98 \%$ of the flood-affected population. During July 29, 2010-September 15, 2010, approximately 5.6 million new patient visits were reported. The most frequent conditions reported were skin diseases (18.3\%), acute respiratory infection (15.1\%), and acute diarrhea (13.3\%). A total of 130 outbreak alerts were documented, of which 115 (88.5\%) were for acute watery diarrhea (AWD) (suspected cholera). Of these, 55 alerts $(47.8 \%)$ had at least one microbiological sample with confirmed cholera. Overall, DEWS was useful in detecting outbreaks, but it was limited by problems with data quality. Improvements in DEWS have increased system usefulness in subsequent emergencies. This report highlights the need to follow updated WHO guidelines on early warning disease surveillance systems to improve their usefulness (1).

\section{Background}

In emergencies before the 2010 floods, the Pakistan National Institute of Health conducted outbreak surveillance in some provinces using an existing DEWS. Severe flooding in July and August of 2010 resulted in $>1,700$ deaths, damaged or destroyed 1.9 million homes, and left at least 10 million people without shelter. This led to the largest international appeal ever (USD 2 billion globally) for humanitarian assistance and a need for an expanded DEWS (2).

\section{Postflood Implementation of DEWS}

After flooding began, DEWS was expanded to a national system covering all flood-affected districts in the country. The primary objective of the system was early outbreak detection and control (Table 1). Disease reporting through this system began in July 2010. In August 2010, WHO requested CDC assistance to strengthen DEWS. Operational guides with standardized case definitions and reporting forms were distributed (3), and national and provincial surveillance staff members were trained. Fixed health facilities and mobile clinics in flood-affected areas were expected to report case counts of 13 conditions considered to be epidemic-prone or of public health importance.* Information was compiled daily at the district, provincial, and national levels, and a national epidemiological bulletin showing aggregated data was issued the following day (4).

DEWS also included an immediate disease alert and response component to meet its primary objective. Most diseases in DEWS had a defined alert threshold (Table 2) that triggered notification of surveillance staff members and outbreak investigation teams. Laboratory confirmation included onsite rapid diagnostic tests and microbiological testing at the national public health laboratory.

The rapid expansion of DEWS was supported by using surveillance personnel and mechanisms for disease reporting from existing provincial systems. Additional resources from vertical, field-based programs, communicable disease programs, and other health programs also were widely used. Lastly, provincial health departments actively supported DEWS implementation by facilitating the training of surveillance officers and mandating disease reporting from district health officers.

\section{Surveillance Results}

Daily reporting began on July 29, 2010. The average weekly number of reporting sites fluctuated between 958 and 1,948 sites for the first 6 weeks. By mid-September 2010, DEWS covered $81(67.5 \%)$ flood-affected districts of the country's 120 districts.

During July 29-September 15, 2010, a total of 5,618,902 patient visits were reported to DEWS. Of those, 2,174,368 $(38.7 \%)$ were for a reportable condition, primarily including 850,292 (15.1\%) visits for acute respiratory infection, 745,532 (13.3\%) for acute diarrhea, and 327,453 (5.8\%) for unexplained fever. In some areas, data on additional conditions were collected using nonstandardized forms and included skin diseases, dog bites, snake bites, eye and ear infections, injuries, and heat stroke. Of these, skin diseases were the most commonly reported, with $1,029,942$ (18.3\% of total) visits.

In the same period, 130 outbreak alerts were generated, of which 115 (88.5\%) were for AWD. Another seven (5.4\%) disease alerts were for suspected measles, two $(1.5 \%)$ were for acute flaccid paralysis, and two $(1.5 \%)$ were for suspected meningitis. Of the AWD alerts, $82(71.3 \%)$ had at least one microbiological sample submitted, with $55(67.1 \%)$ of these

\footnotetext{
*The 13 conditions listed in the guidelines included acute watery diarrhea, bloody diarrhea, acute respiratory infection, suspected malaria, suspected measles, suspected meningitis, acute flaccid paralysis, acute hemorrhagic fever syndrome, acute jaundice syndrome, unexplained fever, unexplained disease occurring in a cluster, other diarrhea, and all other conditions.
} 
samples testing positive for Vibrio cholerae. None of the cases of suspected measles, acute flaccid paralysis, or suspected meningitis were laboratory confirmed as measles, polio, or bacterial meningitis.

\section{Reporting Challenges}

During its rapid implementation, DEWS encountered several challenges common to disease early warning systems established during disasters $(5,6)$. First, application of nonstandard case definitions varied. For example, in Punjab, 311,882 patients with suspected malaria were recorded as having unexplained fever and only 772 confirmed cases were reported as suspected malaria. In contrast, in Sindh, suspected and confirmed malaria cases both were reported as suspected malaria $(n=168,302)$. This affected national estimates. Disease misclassification made the aggregated national data inadequate for identifying and monitoring disease trends.

Second, acceptance of standardized reporting forms varied because some diseases considered important by provincial authorities were not specifically included on DEWS forms (e.g., skin diseases). Hence, provinces used nonstandard forms, which led to the reporting of multiple disease categories inconsistent with standardized DEWS case definitions. A prominent example was diarrhea. In practice, diarrhea was captured as acute diarrhea, bloody diarrhea, AWD, suspected cholera, gastroenteritis, or other diarrhea, depending on the reporting location.

Third, data rarely were analyzed at the district level or lower because staff members were fully occupied fulfilling daily reporting requirements. Data were analyzed and reported nationally, but most outbreak alerts were based on reports of small numbers of cases reported immediately by telephone or e-mail at the local level.

Fourth, disease reporting was difficult to monitor. Lack of reliable information on functioning health facilities and their catchment populations made it difficult to determine timeliness and coverage. Sites reporting fluctuated daily and late or
What is already known on this topic?

After severe flooding in Pakistan in 2010, a large-scale early warning disease surveillance system was implemented. Such systems encounter recurrent challenges in postdisaster settings. What is added by this report?

A national disease early warning system (DEWS) was implemented expeditiously, and during July 29-September 15, 2010, the system captured information from 5,618,902 patient visits and generated 130 outbreak alerts. DEWS was useful for identifying outbreaks, but was limited by poor data quality during initial implementation.

What are the implications for public health practice?

DEWS in Pakistan collected key information on epidemic-prone diseases but experienced challenges with data quality and system usefulness that are well-documented from prior emergencies. Adherence to recently updated World Health Organization guidelines is critical, and ongoing evaluation of the impact of these new guidelines is needed in future emergencies.

missing reports were difficult to track because hundreds of sites reported daily. Although DEWS covered most government health facilities, not all partners delivering health services (e.g., nongovernmental organizations) participated in the system. Data were analyzed using proportionate morbidity and case counts, but with uneven reporting, trends reported in epidemiological bulletins were of limited usefulness.

\section{Recent Situation}

In 2011 and 2012, Pakistan again experienced heavy monsoon flooding, which affected $>4$ million persons each year $(7,8)$. National DEWS continued to operate with weekly reporting and captured 45,510,570 patient visits and 5,752 disease outbreak alerts in 2011 (4). Weekly bulletins were expanded to include subnational trends and outbreak investigation results. Despite early challenges, DEWS remained important for outbreak detection in the absence of other outbreak detection systems.

TABLE 1. Categories of diseases commonly included in early warning disease surveillance systems, by attributes

\begin{tabular}{|c|c|c|}
\hline Attribute & Epidemic-prone diseases & Other diseases of public health importance \\
\hline Objective & Early outbreak detection and response & Monitoring of disease trends \\
\hline Disease characteristics & $\begin{array}{l}\text { Epidemic potential, potential for severe morbidity or } \\
\text { mortality, easy and reliable case identification, available } \\
\text { treatment and prevention and control measures }\end{array}$ & $\begin{array}{l}\text { Cause high morbidity, easy case identification, necessary } \\
\text { for program planning }\end{array}$ \\
\hline Typical diseases & $\begin{array}{l}\text { Acute flaccid paralysis, cholera, measles, bacterial } \\
\text { meningitis }\end{array}$ & $\begin{array}{l}\text { Acute respiratory infection, suspected malaria, acute } \\
\text { nonbloody and nonwatery diarrhea }\end{array}$ \\
\hline Frequency of reporting & Immediate & Less frequent \\
\hline Coverage & Universal & Sentinel \\
\hline Reporting methods & Flexible (e.g., phone, fax, short message service, e-mail) & Designated (e.g., paper, fax, e-mail) \\
\hline Threshold for investigation & Predefined case count threshold & Observed trends related to baseline \\
\hline Data reporting requirements & Minimal & Moderate-high \\
\hline
\end{tabular}


TABLE 2. Disease Early Warning System priority conditions, alert criteria, number of cases, and disease alerts - Pakistan, July 29September 15, 2010*

\begin{tabular}{|c|c|c|c|c|c|c|c|}
\hline \multirow[b]{2}{*}{ Disease } & \multirow[b]{2}{*}{ Case definition } & \multirow[b]{2}{*}{ Alert criteria } & \multirow[b]{2}{*}{ Action suggested } & \multicolumn{2}{|c|}{$\begin{array}{c}\text { Total visits } \\
(\mathrm{N}=5,618,902)\end{array}$} & \multicolumn{2}{|c|}{$\begin{array}{c}\text { Disease alerts } \\
(N=130)\end{array}$} \\
\hline & & & & No. & $(\%)$ & No. & $(\%)$ \\
\hline \multicolumn{8}{|c|}{ Diseases requiring notification and investigation } \\
\hline \multirow[t]{3}{*}{$\begin{array}{l}\text { Acute watery } \\
\text { diarrhea (suspected } \\
\text { cholera) }\end{array}$} & $\begin{array}{l}\text { In an area where cholera is not known to be } \\
\text { present: A person aged }>5 \text { years with severe } \\
\text { dehydration or death from acute watery } \\
\text { diarrhea with or without vomiting }\end{array}$ & $\begin{array}{l}\text { One suspected } \\
\text { case }\end{array}$ & $\begin{array}{l}\text { Reinforce appropriate } \\
\text { case management; } \\
\text { initiate investigation }\end{array}$ & $745.532^{\dagger}$ & $(13.3 \%)$ & 115 & $(88.5 \%)$ \\
\hline & $\begin{array}{l}\text { In an area where there is a cholera outbreak: } \\
\text { A person aged }>5 \text { years with acute watery } \\
\text { diarrhea with or without vomiting }\end{array}$ & & & & & & \\
\hline & $\begin{array}{l}\text { To confirm a case of cholera: Isolation of } \\
\text { Vibrio cholerae } 01 \text { or } 0139 \text { from a } \\
\text { stool sample }\end{array}$ & & & & & & \\
\hline Bloody diarrhea & $\begin{array}{l}\text { Acute diarrhea with visible blood in the stool } \\
\text { To confirm a case of epidemic bacillary } \\
\text { dysentery: Take a stool specimen for } \\
\text { culture and blood for serology; isolation } \\
\text { of Shigella dysenteriae type } 1\end{array}$ & $\begin{array}{l}\text { Three or more } \\
\text { cases in one } \\
\text { location }\end{array}$ & $\begin{array}{l}\text { Reinforce appropriate } \\
\text { case management, } \\
\text { including antibiotic } \\
\text { usage; collect stool for } \\
\text { culture and } \\
\text { antimicrobial } \\
\text { sensitivity; initiate } \\
\text { investigation }\end{array}$ & 49,304 & $(0.9 \%)$ & 1 & $(0.8 \%)$ \\
\hline \multirow[t]{2}{*}{$\begin{array}{l}\text { Acute respiratory } \\
\text { infection }\end{array}$} & $\begin{array}{l}\text { Cough or difficulty breathing and breathing } \\
50 \text { or more times per minute for infants } \\
\text { aged } 2 \text { months to } 1 \text { year / breathing } \geq 40 \text { or } \\
\text { more times per minute for children aged } \\
1-5 \text { years, and no chest indrawing, no } \\
\text { stridor, no general danger signs } \\
\end{array}$ & \multirow[t]{2}{*}{$\begin{array}{l}\text { Twice the } \\
\text { average } \\
\text { number of } \\
\text { cases seen in } \\
\text { the previous } \\
3 \text { weeks for a } \\
\text { given location }\end{array}$} & \multirow[t]{2}{*}{$\begin{array}{l}\text { Reinforce appropriate } \\
\text { case management; } \\
\text { initiate investigation }\end{array}$} & \multirow[t]{2}{*}{850,292} & \multirow[t]{2}{*}{$(15.1 \%)$} & \multirow[t]{2}{*}{0} & \multirow[t]{2}{*}{ - } \\
\hline & $\begin{array}{l}\text { Note: Severe pneumonia = cough or difficulty } \\
\text { breathing and one or more of the following } \\
\text { (inability to drink or breastfeed, severe } \\
\text { vomiting, convulsions, lethargy or } \\
\text { unconsciousness) or chest indrawing or } \\
\text { stridor in an otherwise calm child }\end{array}$ & & & & & & \\
\hline \multirow[t]{4}{*}{ Suspected malaria } & $\begin{array}{l}\text { Current fever or history of fever within the } \\
\text { past } 48 \text { hours (with or without other } \\
\text { symptoms such as nausea, vomiting and } \\
\text { diarrhea, headache, back pain, chills, } \\
\text { muscle pain) }\end{array}$ & \multirow[t]{4}{*}{$\begin{array}{l}\text { Twice the mean } \\
\text { number of } \\
\text { cases seen in } \\
\text { the previous } \\
3 \text { weeks for a } \\
\text { given location }\end{array}$} & \multirow[t]{4}{*}{$\begin{array}{l}\text { Active fever finding and } \\
\text { specimen collection } \\
\text { for laboratory } \\
\text { confirmation }\end{array}$} & \multirow[t]{4}{*}{201,525} & \multirow[t]{4}{*}{$(3.6 \%)$} & \multirow[t]{4}{*}{1} & \multirow[t]{4}{*}{$(0.8 \%)$} \\
\hline & $\begin{array}{l}\text { To confirm a case of malaria: Positive } \\
\text { laboratory test for malaria parasites } \\
\text { (blood film [thick or thin smear] or rapid } \\
\text { diagnostic test) }\end{array}$ & & & & & & \\
\hline & $\begin{array}{l}\text { Uncomplicated malaria: Fever and no general } \\
\text { danger signs such as lethargy or } \\
\text { unconsciousness, convulsions, or inability } \\
\text { to eat or drink. Where possible confirm } \\
\text { malaria with laboratory test }\end{array}$ & & & & & & \\
\hline & $\begin{array}{l}\text { Severe malaria: Fever and general danger } \\
\text { signs (lethargy or unconsciousness, } \\
\text { convulsions, or inability to eat or drink) }\end{array}$ & & & & & & \\
\hline \multirow[t]{2}{*}{ Suspected measles } & $\begin{array}{l}\text { Fever and maculopapular rash } \\
\text { (i.e., nonvesicular) and cough, coryza } \\
\text { (i.e., runny nose) or conjunctivitis (i.e., red } \\
\text { eyes) or any person in whom a clinical } \\
\text { health worker suspects measles infection }\end{array}$ & \multirow[t]{2}{*}{ One case } & \multirow[t]{2}{*}{$\begin{array}{l}\text { Immediate } \\
\text { investigation and } \\
\text { active case finding in } \\
\text { coordination with the } \\
\text { national immunization } \\
\text { program }\end{array}$} & \multirow[t]{2}{*}{60} & \multirow[t]{2}{*}{$(<0.1 \%)$} & \multirow[t]{2}{*}{7} & \multirow[t]{2}{*}{$(5.4 \%)$} \\
\hline & $\begin{array}{l}\text { To confirm a case of measles: Presence of } \\
\text { measles-specific immunoglobulin M }\end{array}$ & & & & & & \\
\hline
\end{tabular}


TABLE 2. (Continued) Disease Early Warning System priority conditions, alert criteria, number of cases, and disease alerts - Pakistan, July 29-September 15,2010 *

\begin{tabular}{|c|c|c|c|c|c|c|c|}
\hline \multirow[b]{2}{*}{ Disease } & \multirow[b]{2}{*}{ Case definition } & \multirow[b]{2}{*}{ Alert criteria } & \multirow[b]{2}{*}{ Action suggested } & \multicolumn{2}{|c|}{$\begin{array}{c}\text { Total visits } \\
(\mathrm{N}=5,618,902)\end{array}$} & \multicolumn{2}{|c|}{$\begin{array}{c}\text { Disease alerts } \\
(N=130)\end{array}$} \\
\hline & & & & No. & (\%) & No. & $(\%)$ \\
\hline \multicolumn{8}{|c|}{ Diseases requiring notification and investigation } \\
\hline \multirow[t]{5}{*}{ Suspected meningitis } & $\begin{array}{l}\text { Sudden onset of fever }\left(>101.3^{\circ} \mathrm{F}\left[>38.5^{\circ} \mathrm{C}\right]\right) \\
\text { with stiff neck. }\end{array}$ & One case & $\begin{array}{l}\text { Reinforce appropriate } \\
\text { case management; }\end{array}$ & 4 & $(<0.1 \%)$ & 2 & $(1.5 \%)$ \\
\hline & $\begin{array}{l}\text { In patients aged }<12 \text { months, a suspected } \\
\text { case of meningitis occurs when fever is } \\
\text { accompanied by a bulging fontanelle }\end{array}$ & & initiate investigation & & & & \\
\hline & $\begin{array}{l}\text { Probable case of bacterial meningitis: } \\
\text { Suspected case of acute meningitis, as } \\
\text { defined above, with turbid cerebrospinal } \\
\text { fluid (CSF) }\end{array}$ & & & & & & \\
\hline & $\begin{array}{l}\text { Probable case of meningococcal meningitis: } \\
\text { Suspected case of acute meningitis, as } \\
\text { defined above, and Gram stain showing } \\
\text { gram-negative diplococcus or ongoing } \\
\text { epidemic or petechial or purpural rash }\end{array}$ & & & & & & \\
\hline & $\begin{array}{l}\text { To confirm a case of meningococcal } \\
\text { meningitis: Suspected case, as defined } \\
\text { above, with either positive-CSF antigen } \\
\text { detection for Neisseria meningitidis or } \\
\text { positive CSF or blood culture with } \\
\text { identification of } N \text {. meningitidis }\end{array}$ & & & & & & \\
\hline $\begin{array}{l}\text { Acute flaccid paralysis } \\
\text { (suspected } \\
\text { poliomyelitis) }\end{array}$ & $\begin{array}{l}\text { Acute flaccid paralysis in a child aged } \\
<15 \text { years, including Guillain-Barre } \\
\text { syndrome, or any acute paralytic illness in a } \\
\text { person of any age in whom poliomyelitis is } \\
\text { suspected }\end{array}$ & $\begin{array}{l}\text { One suspected } \\
\text { case }\end{array}$ & $\begin{array}{l}\text { Case investigation and } \\
\text { specimen collection } \\
\text { for laboratory } \\
\text { diagnosis }\end{array}$ & 9 & $(<0.1 \%)$ & 2 & $(1.5 \%)$ \\
\hline $\begin{array}{l}\text { Acute hemorrhagic } \\
\text { fever syndrome }\end{array}$ & $\begin{array}{l}\text { Acute onset of fever (duration of }<3 \text { weeks) } \\
\text { and any of the following: hemorrhagic or } \\
\text { purpuric rash, vomiting with blood, cough } \\
\text { with blood, blood in stools, epistaxis, other } \\
\text { hemorrhagic symptoms }\end{array}$ & & $\begin{array}{l}\text { Initiate verification and } \\
\text { investigation as } \\
\text { required }\end{array}$ & 0 & & 1 & $(0.8 \%)$ \\
\hline $\begin{array}{l}\text { Acute jaundice } \\
\text { syndrome }\end{array}$ & $\begin{array}{l}\text { Illness with acute onset of jaundice and } \\
\text { absence of any known precipitating factors } \\
\text { and/or fever }\end{array}$ & $\begin{array}{l}\text { Three of more } \\
\text { cases in one } \\
\text { location }\end{array}$ & $\begin{array}{l}\text { Initiate verification and } \\
\text { investigation as } \\
\text { required. Specimen } \\
\text { collection for } \\
\text { laboratory } \\
\text { confirmation }\end{array}$ & 189 & $(<0.1 \%)$ & 0 & - \\
\hline Unexplained fever & $\begin{array}{l}\text { Fever (body temperature }>101.3^{\circ} \mathrm{F}\left[>38.5^{\circ} \mathrm{C}\right] \text { ) } \\
\text { for }>48 \text { hours and without other known } \\
\text { etiology }\end{array}$ & $\begin{array}{l}\text { One death or } \\
\text { two times the } \\
\text { mean number } \\
\text { of cases of the } \\
\text { previous } 3 \\
\text { weeks for a } \\
\text { given location }\end{array}$ & Initiate investigation & 327,453 & $(5.8 \%)$ & 0 & - \\
\hline $\begin{array}{l}\text { Unknown disease } \\
\text { occurring in cluster }\end{array}$ & $\begin{array}{l}\text { An aggregation of cases with similar } \\
\text { symptoms and signs of unknown cause that } \\
\text { are closely grouped in time and/or place }\end{array}$ & $\begin{array}{l}\text { An aggregation } \\
\text { of cases with } \\
\text { related } \\
\text { symptoms and } \\
\text { signs of } \\
\text { unknown cause } \\
\text { that are closely } \\
\text { grouped in time } \\
\text { and/or place }\end{array}$ & $\begin{array}{l}\text { Initiate verification and } \\
\text { investigation } \\
\text { as required }\end{array}$ & 0 & & 0 & - \\
\hline
\end{tabular}

See table footnotes on page 1006. 
Morbidity and Mortality Weekly Report

TABLE 2. (Continued) Disease Early Warning System priority conditions, alert criteria, number of cases, and disease alerts - Pakistan, July 29-September $15,2010^{*}$

\begin{tabular}{|c|c|c|c|c|c|c|c|}
\hline \multirow[b]{2}{*}{ Disease } & \multirow[b]{2}{*}{ Case definition } & \multirow[b]{2}{*}{ Alert criteria } & \multirow[b]{2}{*}{ Action suggested } & \multicolumn{2}{|c|}{$\begin{array}{c}\text { Total visits } \\
(\mathrm{N}=5,618,902) \\
\end{array}$} & \multicolumn{2}{|c|}{$\begin{array}{c}\text { Disease alerts } \\
(\mathrm{N}=130) \\
\end{array}$} \\
\hline & & & & No. & (\%) & No. & (\%) \\
\hline \multicolumn{8}{|c|}{ Other diseases of public health importance } \\
\hline Other diarrhea & $\begin{array}{l}\text { Acute diarrhea (passage of three or more } \\
\text { loose stools in the past } 24 \text { hours) with or } \\
\text { without dehydration, and which is not } \\
\text { because of bloody or watery diarrhea }\end{array}$ & & & $745,532^{\dagger}$ & $(13.3 \%)$ & - & - \\
\hline Other diseases & $\begin{array}{l}\text { Including skin diseases, dog bites, snake } \\
\text { bites, eye and ear infections, injuries, heat } \\
\text { stroke, and other diseases }\end{array}$ & & & $3,444,534$ & $(61.3 \%)$ & 1 & $(0.8 \%)^{n}$ \\
\hline
\end{tabular}

* Source: Outbreak surveillance and response, disease early warning system, flooding response in Pakistan, operational guidance, August 2010. Available at http://www.who.int/hac/crises/pak/pakistan_operational_guidance_flooding_august2010.pdf.

$\dagger$ Diarrhea was reported as acute diarrhea, which included acute watery diarrhea and other diarrhea.

$\S$ Not specified.

I Leishmaniasis.

\section{Reported by}

Guido Sabatinelli, MD, Suzette Rene Kakar, MD, Musa Rahim Khan, MD, Mamunur Malik, MBBS, World Health Organization, Pakistan. Birjees Mazher Kazi, MBBS, Pakistan National Institute of Health. Jahanzeb Khan Aurakzai, MBBS, Pakistan National Emergency Preparedness and Response Network. Michelle Gayer, MBBS, Disease Control in Humanitarian Emergencies, World Health Organization. Farah Husain, DMD, Muireann Brennan, MD, Oleg Bilukha, MD, PhD, Irshad Shaikh, MD, PhD, Susan Cookson, MD, Div of Global Disease Detection and Emergency Response, Center for Global Health; Cyrus Shahpar, MD, EIS Officer, CDC. Corresponding contributor: CyrusShahpar, cshahpar@cdc.gov, 770-488-3920.

\section{Editorial Note}

This report describes the implementation of a postdisaster DEWS in Pakistan. The challenges of DEWS implementation mirror those of other early warning alert and response network (EWARN) surveillance systems, which have been documented in many emergencies, including Sudan, Darfur, Haiti, and Pakistan, and discussed at two WHO technical workshops $(9,10)$.

The primary objective of an EWARN system is early detection of and response to epidemic-prone diseases. In a major emergency, EWARN systems should be implemented expeditiously and should focus on that objective. Alerts of typically rarer diseases should trigger timely investigation and control measures. In practice, however, EWARN systems frequently include monitoring of other infectious diseases of public health importance, that occur more frequently, as they did in Pakistan. This is problematic because reporting of these more common diseases can overwhelm resources, negatively affect data quality, and potentially detract from outbreak detection.

Existing nonemergency surveillance systems can be used to capture information on the more common diseases, or reporting from select sentinel sites might suffice to assess trends. In this case, reporting sites should be chosen based on reliability of reporting, representativeness, and other factors that maximize data quality and the ability to respond in a timely manner.

Implementation and coordination of EWARN systems must be improved. Data collection forms with standardized case definitions should be developed in consultation with local partners to maximize acceptance and should be widely distributed in paper form and electronically. Systems should be designed to include available technologies (e.g., short message service data collection), but also have contingency plans should infrastructure fail. Multiple training sessions are required because of high staff turnover in emergencies. Local staff members should be trained to enter and analyze data and receive frequent feedback, so they can use the information they report for public health action and appreciate the benefits of reporting.

In 2010, DEWS exemplified the value and challenges of early warning disease surveillance, and it was a functional system despite the massive scope of the emergency. In 2012, WHO released updated operational guidelines on EWARN implementation, based on evidence gained from prior implementations in Pakistan and other countries (1). These guidelines target many of the documented challenges of EWARN implementation. Further evaluations are needed to determine whether adherence to new guidelines results in improvements in the quality and usefulness of surveillance data. 


\section{References}

1. World Health Organization. Outbreak surveillance and response in humanitarian emergencies: WHO guidelines for EWARN implementation; 2012. Geneva, Switzerland: World Health Organization; 2012. Available at http://www.who.int/diseasecontrol_emergencies/ publications/who_hse_epr_dce_2012.1/en/index.html. Accessed March 30, 2012.

2. United Nations Office for the Coordination of Humanitarian Affairs. Pakistan floods relief and early response recovery plan revision, November 2010. Islamabad, Pakistan: United Nations Office for the Coordination of Humanitarian Affairs; 2010. Available at http://reliefweb.int/report/ pakistan/pakistan-floods-relief-and-early-recovery-response-planrevision-november-2010. Accessed December 10, 2011.

3. World Health Organization. Outbreak surveillance and response, disease early warning system, flooding response in Pakistan, operational guidance, August 2010. Geneva, Switzerland: World Health Organization; 2010. Available at http://www.who.int/hac/crises/pak/ pakistan_operational_guidance_flooding_august2010.pdf. Accessed February 8, 2011.

4. National Institute of Health, World Health Organization. Disease early warning system and response in Pakistan. Wkly Epidemiol Bull 2012:3(1).

5. CDC. Launching a national surveillance system after an earthquakeHaiti, 2010. August 6, 2010. MMWR 2010;9:933-8.
6. CDC. Rapid establishment of an internally displaced persons disease surveillance system after an earthquake-Haiti, 2010. MMWR 2010;9:939-45.

7. US Agency for International Development. Pakistan-floods. Fact sheet no. 1, fiscal year (FY) 2012. October 3, 2011. Washington, DC: US Agency for International Development; 2012. Available at http:// reliefweb.int/sites/reliefweb.int/files/resources/10.03.11\%20-\%20usaiddcha\%20pakistan $\% 20$ floods\%20fact $\% 20$ sheet $\% 20 \% 231 \% 20-\% 20$ fy\%202012.pdf. Accessed October 11, 2011.

8. United Nations Office for the Coordination of Humanitarian Affairs. Pakistan: monsoon 2012 situation report no. 2. October 3, 2012. Islamabad, Pakistan: United Nations Office for the Coordination of Humanitarian Affairs; 2012. Available at http://reliefweb.int/sites/ reliefweb.int/files/resources/OCHA_Pakistan_Monsoon_2012_Sitrep23Oct2012.pdf. Accessed December 7, 2012.

9. World Health Organization. Early warning surveillance and response in emergencies. Report of the WHO technical workshop. December 7-8, 2009. Geneva, Switzerland: World Health Organization; 2009. Available at http://whqlibdoc.who.int/hq/2010/who_hse_gar_dce_2010.4_eng.pdf. Accessed February 1, 2011.

10. World Health Organization. Early warning surveillance and response in emergencies. Report of the second WHO technical workshop. May 10-11, 2010. Geneva, Switzerland: World Health Organization; 2010. Available at http://whqlibdoc.who.int/hq/2010/who_hse_gar_ dce_2010.4_eng.pdf. Accessed March 1, 2012. 


\section{Expanding Poliomyelitis and Measles Surveillance Networks to Establish Surveillance for Acute Meningitis and Encephalitis Syndromes - Bangladesh, China, and India, 2006-2008}

\section{Introduction}

Quality surveillance is critical to the control and elimination of vaccine-preventable diseases (VPDs). A key strategy for enhancing VPD surveillance, outlined in the World Health Organization (WHO) Global Framework for Immunization Monitoring and Surveillance (GFIMS) (1), is to expand and link existing VPD surveillance systems (particularly those developed for polio eradication and measles elimination) to include other priority VPDs. Since the launch of the Global Polio Eradication Initiative in 1988, the incidence of polio has decrease by $99 \%$ worldwide (2). A cornerstone of this success is a sensitive surveillance system based on the rapid and timely reporting of all acute flaccid paralysis (AFP) cases in children aged $<15$ years, with confirmatory diagnostic testing performed by laboratories that are part of a global network. As countries achieve polio-free status, many have expanded syndromic surveillance to include persons with rash and fever, and have built measles diagnostic capacity in existing polio reference laboratories. Acute meningitis/encephalitis syndrome (AMES)* and acute encephalitis syndrome (AES) ${ }^{\dagger}$ are candidates for expanded surveillance because they are most often caused by VPDs of public health importance for which confirmatory laboratory tests exist. Vaccine-preventable cases of encephalitis include approximately 68,000 Japanese encephalitis (JE) cases, resulting in 13,000-20,000 deaths each year in Asia (3). Moreover, although bacterial meningitis incidence in Asia is not as well-documented, pneumococcal and meningococcal meningitis outbreaks have been reported in Bangladesh (4) and China (5), and the incidence of Haemophilus influenzae type $\mathrm{b}(\mathrm{Hib})$ meningitis in children aged $<5$ years in India has been estimated to be 7.1 per 100,000 population, similar to that in European countries before the introduction of vaccine (6). This report describes a prototype for expanding existing polio and measles surveillance networks in Bangladesh, China, and India to include surveillance for viral and bacterial vaccinepreventable causes of AMES and AES and presents data from 2006-2008.

\footnotetext{
*An acute febrile illness with at least one of the following: altered mental status, new-onset seizures, or signs of meningeal irritation in a person of any age at any time of year.

$\dagger$ An acute febrile illness with at least one of the following: altered mental status or new-onset seizures in a person of any age at any time of year.
}

\section{Background}

AMES and AES surveillance rely on identification of persons presenting with a clinically compatible syndrome, collection and testing of specimens, and laboratory confirmation $(7,8)$. During 2006-2008, Bangladesh and China introduced AMES surveillance, and India introduced AES surveillance. In all three countries, surveillance was initiated in areas with well-established AFP and rash/fever surveillance systems, high AFP performance indicators, no endemic polio transmission, $\$$ and expressed interest by their ministries of health (MoHs) to introduce AMES/AES surveillance.

\section{Implementation}

Active AMES/AES surveillance was established at sentinel hospitals in three districts of Bangladesh (three sites), four prefectures in four provinces of China (24 sites), and four states of India (four sites). Case investigations were conducted by polio and hospital surveillance medical officers (Bangladesh and India) and VPD surveillance staff (China). Blood and cerebrospinal fluid (CSF) were collected from patients at sentinel sites who had an illness that met the clinical case definition. Case investigation data were entered into standardized electronic data management systems that were developed separately for each implementing country. Every month, summary results were reported by the respective national program office to the $\mathrm{MoH}$, which provided feedback to sentinel sites.

The laboratory methods, staff, and equipment needed for JE diagnosis were similar to those used for measles testing, and JE testing was conducted by the global polio/measles network laboratories and staff members. JE was diagnosed by detecting anti-JE virus immunoglobulin $\mathrm{M}(\mathrm{IgM})$ in CSF or serum by IgM-capture enzyme-linked immunosorbent assay at the National Institute of Public Health (Bangladesh), the Chinese Center for Disease Control and Prevention (CCDC) prefectural laboratories (China), and sentinel hospital laboratories (India).

Because considerable personnel, procedural, and specimenprocessing differences exist between indirect viral assays and bacterial cultures, bacterial testing was difficult to establish in the polio/measles viral laboratories. Bacterial culture, Gram stain, and latex agglutination (LA) were performed at sentinel hospital laboratories in Bangladesh and China for bacterial

\footnotetext{
$\$$ Endemic polio transmission was occurring in India; however, the states selected for AES surveillance had no ongoing transmission.
} 
(i.e., Neisseria meningitidis, Streptococcus pneumoniae, and Hib) meningitis etiologies (Figure). When specimens were adequate, real-time polymerase chain reaction (rt-PCR) for Hib, S. pneumoniae, and $N$. meningitidis was performed on CSF or serum (or both) at CDC (Bangladesh) and on CSF at the CCDC provincial laboratories (China). CDC provided training, reference strains, and proficiency panel testing for quality assurance and quality control (QA/QC).

During 2006-2008, a total of 4,197 AMES/AES patients were reported from Bangladesh $(n=632)$, China $(n=2,815)$ and India $(n=750)$. For $\geq 90 \%$ of these, specimens were tested in the AMES/AES laboratory network (Table 1).

FIGURE. Functions of various components of AMES/AES surveillance and laboratory networks — China, Bangladesh, and India, 2006-2008

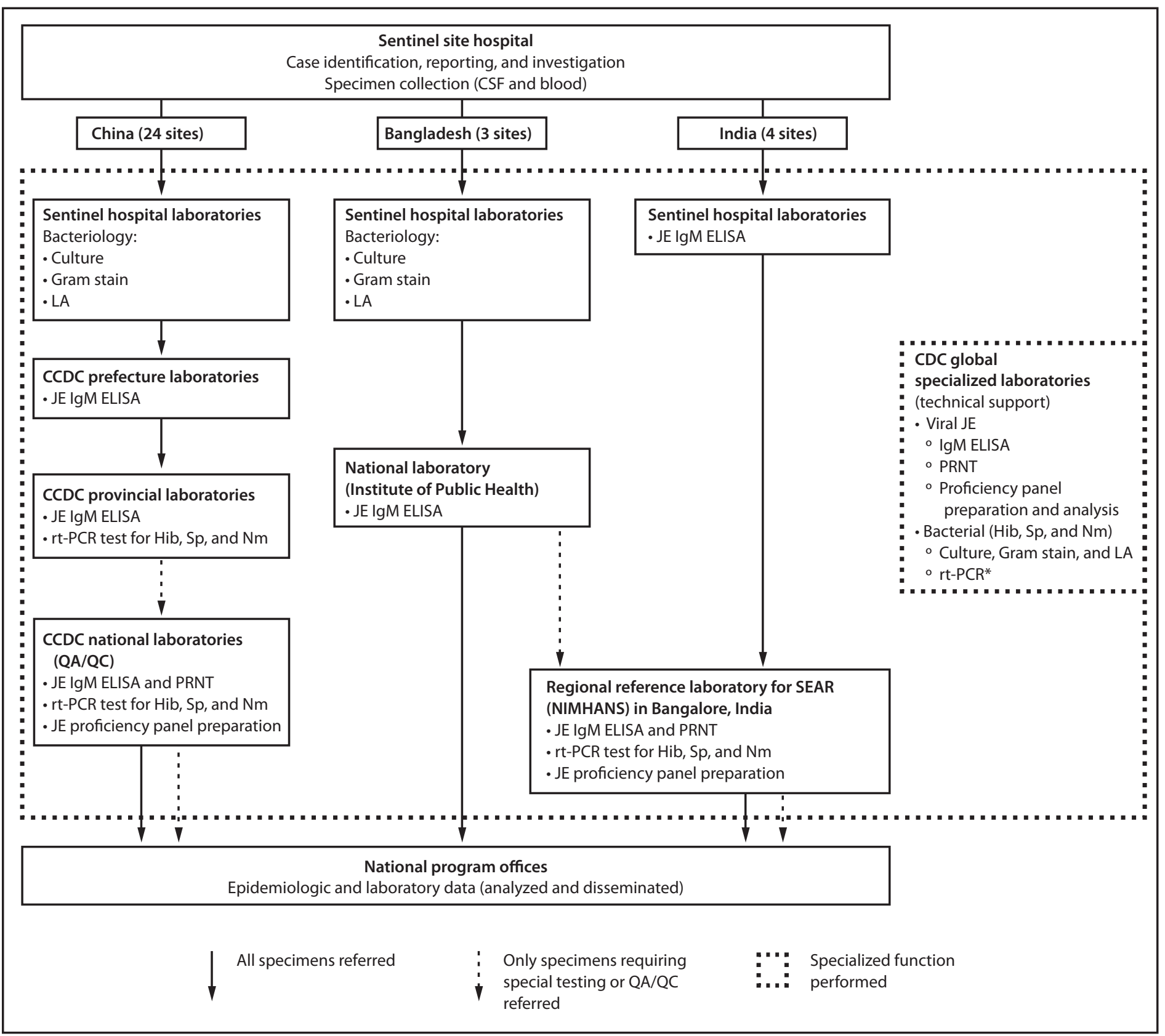

Abbreviations: $\mathrm{AMES}=$ acute meningitis/encephalitis syndrome; $\mathrm{AES}=$ acute encephalitis syndrome; $\mathrm{CSF}=$ cerebrospinal fluid; $\mathrm{LA}=$ latex agglutination; JE = Japanese encephalitis; IgM = immunoglobulin M; ELISA = enzyme-linked immunosorbent assay; CCDC = Chinese Center for Disease Control; rt-PCR = real-time polymerase chain reaction; Hib = Haemophilus influenzae type b; $\mathrm{Sp}=$ Streptococcus pneumoniae; $\mathrm{Nm}=$ Neisseria meningitidis; PRNT = plaque reduction neutralization test; $\mathrm{QA} / \mathrm{QC}=$ quality assurance/quality control; WHO SEAR = World Health Organization South-East Asia Region; NIMHANS = National Institute of Mental Health and Neurosciences.

* CDC performed rt-PCR on CSF/serum for detection of Hib, Sp, and Nm for Bangladesh. 
Morbidity and Mortality Weekly Report

TABLE 1. AMES*/AES ${ }^{\dagger}$ case reporting and specimen collection, by selected characteristics — China, Bangladesh, and India, 2006-2008

\begin{tabular}{|c|c|c|c|c|c|c|}
\hline \multirow[b]{2}{*}{ Sentinel site } & \multirow[b]{2}{*}{ Surveillance type } & \multirow[b]{2}{*}{ Reporting period } & \multirow[b]{2}{*}{ No. of cases reported } & \multicolumn{3}{|c|}{ No. (\%) of cases with specimen collected } \\
\hline & & & & Blood or CSF & Blood & CSF \\
\hline China & AMES & Sept 2006-Sept 2008 & 2,815 & $2,728(97)$ & $2,681(95)$ & $2,081(74)$ \\
\hline Bangladesh & AMES & Oct 2007-Aug 2008 & 632 & $569(90)$ & $622(98)$ & $447(71)$ \\
\hline India & AES & May 2007-April 2008 & 750 & $718(96)$ & $369(49)$ & $451(60)$ \\
\hline
\end{tabular}

Abbreviations: $\mathrm{AMES}=$ acute meningitis/encephalitis syndrome; $\mathrm{AES}=$ acute encephalitis syndrome; CSF = cerebrospinal fluid.

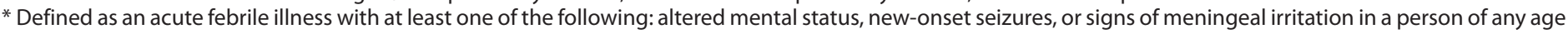
at any time of year.

${ }^{\dagger}$ Defined as an acute febrile illness with at least one of the following: altered mental status or new-onset seizures in a person of any age at any time of year.

\section{Comment}

Field surveillance, including case investigations, was well integrated into existing polio and measles surveillance activities, which historically have been conducted through the immunization program in Bangladesh, China, and India. Other $\mathrm{MoH}$ departments had responsibility for JE surveillance (Bangladesh and India) and bacterial meningitis surveillance (Bangladesh, China, and India).

AMES/AES viral laboratory testing for JE was integrated successfully into the polio and measles networks in all three countries. However, development of capacity for bacterial meningitis diagnosis proved to be more challenging (Table 2). Because hospitals have primary responsibility for conducting bacterial testing to determine appropriate treatment, hospital laboratories routinely process blood and CSF for bacterial culture, whereas specimens for viral testing are sent to a surveillance reference laboratory (Figure). In many settings, CSF specimens were not collected or were collected after initiation of antibiotic therapy, and delays in processing, storage, and shipping affected culture results. In addition, although standard operating and QA/QC procedures exist for the polio and measles laboratory network, at the time of this activity, there were no established WHO-sponsored networks with standard operating and QA/QC procedures or an accreditation process for laboratories diagnosing bacterial diseases. Because hospital and public health bacteriology laboratories usually fall under a different jurisdiction than polio and measles surveillance reference viral laboratories, developing capacity in these laboratories requires building new relationships at national, provincial, and local levels. National bacteriology laboratories have not received the same level of attention and resources as have global surveillance networks for polio and measles.

WHO's global invasive bacterial vaccine-preventable disease (IB-VPD) surveillance and laboratory network was established in 2008 and is an important step towards providing the needed support, standardization, and quality assurance for bacterial testing in participating countries.
To enhance detection of bacterial meningitis, efforts were made to standardize laboratory quality at the sentinel hospital laboratories and to establish standard operating procedures, $\mathrm{QA} / \mathrm{QC}$ procedures, and reference testing for laboratory diagnosis of bacterial diseases. To compensate for the limitations of bacterial culture, where resources are available, rt-PCR can be used to enhance the sensitivity of laboratory-supported bacterial meningitis surveillance (9).

Funding for surveillance often is disease-specific and timelimited, and can result in multiple, parallel surveillance systems that compete for resources, are not adequately funded, and are not sustainable. As the number of diseases targeted by immunization increases, the need for integrated surveillance systems also will increase (10). This effort to introduce AMES/AES surveillance was funded by CDC's Division of Global Disease Detection and Emergency Response.

This surveillance project represents the first effort to integrate surveillance for encephalitis and meningitis at the field and laboratory levels, capitalizes on the existing infrastructure and international investment in polio and measles surveillance, and should be considered one approach to implementing GFIMS. In China, the $\mathrm{MoH}$ assumed full funding of the project in 2010 and has been sustaining AMES surveillance in four provinces since then. Since 2010, Bangladesh, using local and external resources, has expanded AMES surveillance to include an additional sentinel site, for a total of four sentinel sites. All of India's AES surveillance sites have been sustained with local resources. Additionally, these sentinel sites are being integrated into the IB-VPD network as feasible. Lessons learned from this effort to integrate AMES/AES surveillance into existing VPD surveillance can inform planned integration programs in other areas. Successful implementation of GIFMS depends upon development of best practices, which can be applied to other integrated VPD surveillance projects. 
TABLE 2. Elements of surveillance for AMES*/AES ${ }^{\dagger}$ surveillance and status of success in integration with polio and measles syndromic and laboratory surveillance - China, Bangladesh, and India, 2006-2008

\begin{tabular}{|c|c|c|c|c|c|c|c|}
\hline \multirow[b]{2}{*}{ Component } & \multirow[b]{2}{*}{ Element } & \multicolumn{3}{|c|}{ Successful integration of viral and JE surveillance } & \multicolumn{3}{|c|}{ Successful integration of bacterial meningitis surveillance } \\
\hline & & Yes & No & Reason (if no) & Yes & No & Reason (if no) \\
\hline Field surveillance & $\begin{array}{l}\text { Case definition } \\
\text { Clinical presentation } \\
\text { Case finding } \\
\text { Clinicians } \\
\text { Human resources }\end{array}$ & $\begin{array}{l}\sqrt{ } \\
\sqrt{ } \\
\sqrt{ } \\
\sqrt{ } \\
\sqrt{ }\end{array}$ & & & $\begin{array}{l}\sqrt{ } \\
\sqrt{ } \\
\sqrt{ } \\
\sqrt{ } \\
\sqrt{ }\end{array}$ & & \\
\hline \multirow[t]{4}{*}{ Laboratories } & $\begin{array}{l}\text { Equipment } \\
\text { Testing methods } \\
\text { Technical capacity } \\
\text { Specimens (Blood/CSF) }\end{array}$ & $\begin{array}{l}\sqrt{ } \\
\sqrt{ } \\
\sqrt{ }\end{array}$ & & & & $\begin{array}{l}\sqrt{ } \\
\sqrt{ } \\
\sqrt{ }\end{array}$ & $\begin{array}{l}\text { Different equipment } \\
\text { Different tests } \\
\text { Microbiologist (no); Technician (no) }\end{array}$ \\
\hline & Type & & $\sqrt{ }$ & $\begin{array}{l}\text { Blood (yes); CSF for polio/ } \\
\text { measles (no) }\end{array}$ & & $\sqrt{ }$ & Blood (yes); CSF (no) \\
\hline & $\begin{array}{l}\text { Collection } \\
\text { Handling }\end{array}$ & $\sqrt{ }$ & $\sqrt{ }$ & Different collection method & & $\begin{array}{l}\sqrt{ } \\
\sqrt{ }\end{array}$ & $\begin{array}{l}\text { Different collection method } \\
\text { Different temperature and } \\
\text { container requirements }\end{array}$ \\
\hline & Stability & $\sqrt{ }$ & & & & $\sqrt{ }$ & Bacteria (fastidious) \\
\hline \multirow[t]{2}{*}{ Data management } & $\begin{array}{l}\text { Staff } \\
\text { Software }\end{array}$ & $\sqrt{ }$ & $\sqrt{ }$ & $\begin{array}{l}\text { Different software (different } \\
\text { variables) }\end{array}$ & $\sqrt{ }$ & $\sqrt{ }$ & $\begin{array}{l}\text { Different software (different } \\
\text { variables) }\end{array}$ \\
\hline & $\begin{array}{l}\text { Hardware } \\
\text { Data analysis }\end{array}$ & $\begin{array}{l}\sqrt{ } \\
\sqrt{ }\end{array}$ & & & $\begin{array}{l}\sqrt{ } \\
\sqrt{ }\end{array}$ & & \\
\hline
\end{tabular}

Abbreviations: $\mathrm{AMES}=$ acute meningitis/encephalitis syndrome; $\mathrm{AES}=$ acute encephalitis syndrome; JE = Japanese encephalitis; CSF = cerebrospinal fluid.

* Defined as an acute febrile illness with at least one of the following: altered mental status, new-onset seizures, or signs of meningeal irritation in a person of any age at any time of year.

${ }^{\dagger}$ Defined as an acute febrile illness with at least one of the following: altered mental status or new-onset seizures in a person of any age at any time of year.

\section{Reported by}

National Immunization Program, Institute for Viral Disease Control, Institute for Communicable Disease Control, Chinese Center for Disease Control and Prevention; Expanded Programme on Immunization, World Health Organization, China. National Vector Borne Disease Control Programme, Ministry of Health and Family Welfare; National Institute of Mental Health and Neurosciences; National Polio Surveillance Project, World Health Organization, New Delhi; Expanded Programme on Immunization, Immunization and Vaccine Development, Family and Health Research Dept, World Health Organization Regional Office for South-East Asia, New Delhi, India. Institute for Epidemiology, Disease Control, and Research, Institute of Public Health, Ministry of Health and Family Welfare, Bangladesh. International Centre for Diarrheal Diseases Research; Immunization and Vaccine Development, World Health Organization, Bangladesh. Expanded Programme on Immunization, World Health Organization Regional Office for the Western Pacific, Philippines. Expanded Programme on Immunization, World Health Organization, Switzerland. Div of Vector-Borne Diseases, National Center for Emerging and Zoonotic Diseases; Div of Bacterial Diseases, Div of Viral Diseases, National Center for Immunization and Respiratory Diseases; Global Immunization Division, Centre for Global Health, CDC. Corresponding contributor: Hardeep S. Sandhu, hsandhu@cdc.gov, 404-639-8976.

\section{References}

1. World Health Organization. Global Framework for Immunization Monitoring and Surveillance. Geneva, Switzerland: World Health Organization; 2007. Available at http://whqlibdoc.who.int/hq/2007/ who_ivb_07.06_eng.pdf. Accessed December 5, 2012.

2. World Health Assembly. Global eradication of poliomyelitis by the year 2000. Resolution WHA41.28. Geneva, Switzerland: World Health Organization; 1988. Available at http://www.who.int/ihr/ polioresolution4128en.pdf. Accessed December 12, 2012.

3. Campbell GL, Hills SL, Fischer M, et al. Estimated global incidence of Japanese encephalitis: a systematic review. Bull World Health Organ 2011;89:766-74.

4. Gurley ES, Hossain MJ, Montgomery SP, et al. Etiologies of bacterial meningitis in Bangladesh: results from a hospital-based study. Am J Trop Med Hyg 2009;81:475-83.

5. Shao Z, Li W, Ren J, et al. Identification of a new Neisseria meningitidis serogroup C clone from Anhui province, China. Lancet 2006;367:419-23.

6. Minz S, Balraj V, Lalitha MK, et al. Incidence of Haemophilus influenzae type b meningitis in India. Indian J Med Res 2008;128:57-64.

7. World Health Organization. Polio laboratory network. Geneva, Switzerland: World Health Organization; 2012. Available at http://www. who.int/immunization_monitoring/laboratory_polio/en/index.html. Accessed December 5, 2012.

8. World Health Organization. Measles and rubella laboratory network. Geneva, Switzerland: World Health Organization; 2012. Available at http://www.who.int/immunization_monitoring/laboratory_measles/en. Accessed December 5, 2012.

9. World Health Organization. Global invasive bacterial vaccine preventable diseases (IB-VPD) information and surveillance bulletin, January-June 2011. Vol 5. Geneva, Switzerland: World Health Organization; 2012. Available at http://www.who.int/nuvi/surveillance/IB_VPD_bulletin_ Jan_June_2011_Final.pdf. Accessed December 5, 2012.

10. Dabbagh A, Eggers R, Cochi S, Dietz V, Strebel P, Cherian T. A new global framework for immunization monitoring and surveillance. Bull World Health Organ 2007;85:904-5. 


\section{Vol. 61, No. 47}

In the report, "Take-Home Lead Exposure Among Children with Relatives Employed at a Battery Recycling Facility Puerto Rico, 2011," an error occurred on page 967 in the sixth sentence of the first paragraph. That sentence should read, "Eighty-five percent of vehicle dust samples and 49\% of home dust samples exceeded the U.S. Environmental Protection Agency (EPA) level of concern of $\geq 40 \mu \mathrm{g} / \mathrm{ft}^{2}\left(430.6 \mu \mathrm{g} / \mathrm{m}^{2}\right)$." 


\section{Percentage of Emergency Department Visits by Persons Aged $\leq 18$ Years, by Primary Expected Source of Payment — National Hospital Ambulatory Medical Care Survey, United States, 2001-2002 to 2009-2010}

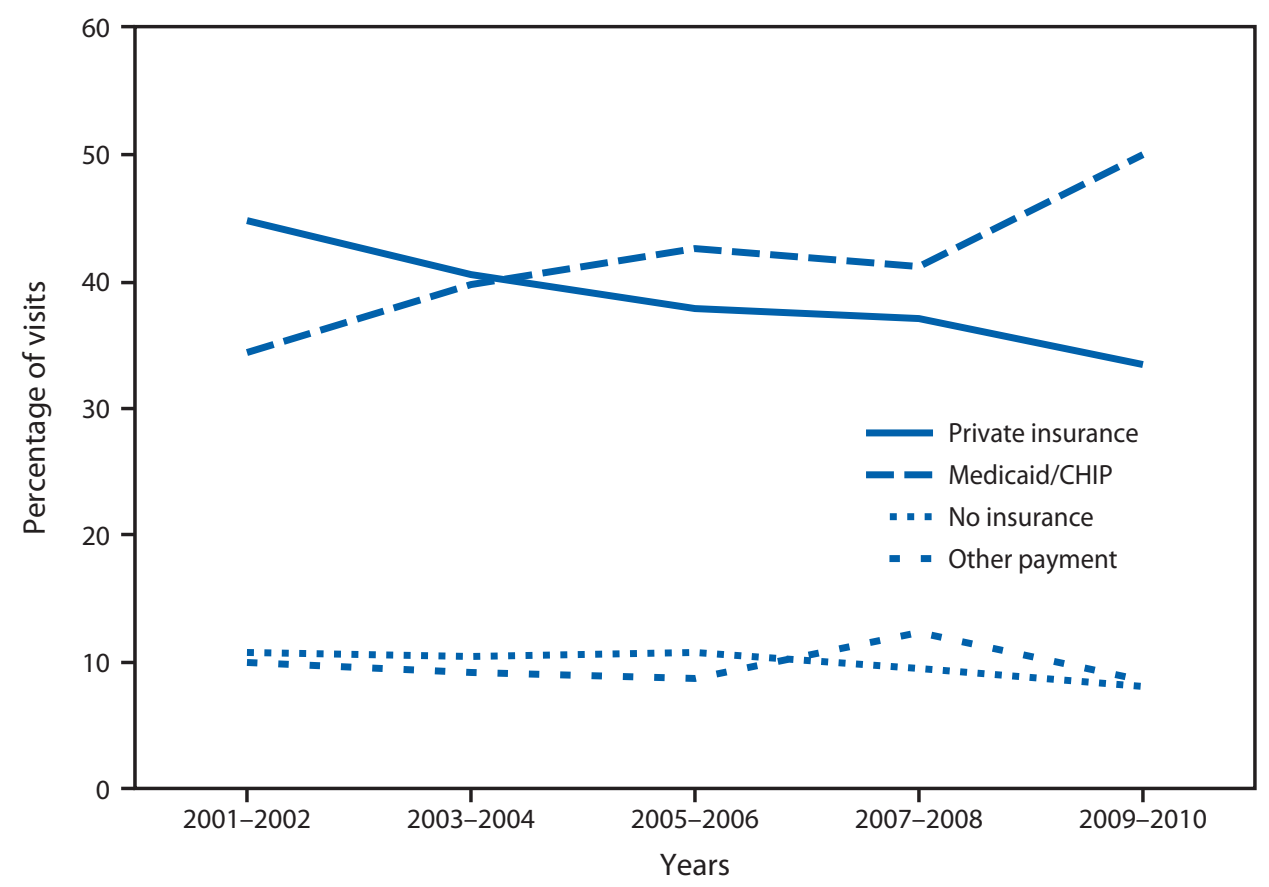

Abbreviation: CHIP = Children's Health Insurance Program.

During 2009-2010, Medicaid or CHIP was the primary expected payment source for $50 \%$ of visits to an emergency department by persons aged $\leq 18$ years, up from $34 \%$ during $2001-2002$. During the same period, the percentage of visits with private insurance as the primary payment source decreased from $45 \%$ to $34 \%$, and the percentage of visits with no insurance payment decreased from $11 \%$ to $8 \%$.

Source: National Hospital Ambulatory Medical Care Survey 2001-2010. Available at http://www.cdc.gov/nchs/ahcd.htm.

Reported by: Michael Albert, MD, wmy1@cdc.gov, 301-458-4223; Linda F. McCaig, MPH. 


The Morbidity and Mortality Weekly Report (MMWR) Series is prepared by the Centers for Disease Control and Prevention (CDC) and is available free of charge in electronic format. To receive an electronic copy each week, visit $M M W R$ 's free subscription page at http://www.cdc.gov/mmwr/mmwrsubscribe. $\mathrm{html}$. Paper copy subscriptions are available through the Superintendent of Documents, U.S. Government Printing Office, Washington, DC 20402; telephone 202-512-1800.

Data presented by the Notifiable Disease Data Team and 122 Cities Mortality Data Team in the weekly MMWR are provisional, based on weekly reports to CDC by state health departments. Address all inquiries about the MMWR Series, including material to be considered for publication, to Editor, MMWR Series, Mailstop E-90, CDC, 1600 Clifton Rd., N.E., Atlanta, GA 30333 or to mmwrq@cdc.gov.

All material in the MMWR Series is in the public domain and may be used and reprinted without permission; citation as to source, however, is appreciated. Use of trade names and commercial sources is for identification only and does not imply endorsement by the U.S. Department of Health and Human Services.

References to non-CDC sites on the Internet are provided as a service to $M M W R$ readers and do not constitute or imply endorsement of these organizations or their programs by CDC or the U.S. Department of Health and Human Services. CDC is not responsible for the content of these sites. URL addresses listed in $M M W R$ were current as of the date of publication.

U.S. Government Printing Office: 2012-623-030/02042 Region IV ISSN: 0149-2195 